\title{
Analisis Kadar Tanin Dalam Buah Mangrove Avicennia marina Dengan Perebusan Dan Lama Perendaman Air Yang Berbeda
}

\author{
Nirwani Soenardjo dan Endang Supriyantini \\ Departemen IImu Kelautan, Fakultas Perikanan dan IImu Kelautan, Universitas Diponegoro \\ JI. Prof. Soedarto, SH. Kampus UNDIP Tembalang, Semarang 50275 \\ Email : nirwanisoenardjo@gmail.com
}

\begin{abstract}
Mangrove fruit has the potential to be developed as a potential food source, but the presence of toxins in the fruit are considered harmful if consumed in the long run. Therefore, research needs to be done to eliminate or reduce the levels of toxins in the mangrove fruit, in order to increase the potential of the mangrove plants. The poison is in the mangrove fruit tannins. One alternative to reduce the levels of toxins in the fruit of the mangrove scrub with ash and water immersion.The purpose of this study was to determine the effect of treatment of ash powder content and the duration of water immersion on fruit tannin content of mangrove Avicennia.marina.The treatment was a long 24 hours of water immersion 4 times change of water (6 hours), 48 hours 8 times a change of water (6 hours), and 72 hours 12 times a change of water ( 6 hours). The results showed that treatment long soaking water to give a significant influence $(P<0.05)$ toward decreased levels of mangrove Avicennia marina fruit tannins. Treatment a long 72 hours of water immersion 12 times a change of water 16 hours) to reduce levels of tannins by $28.80 \%$.
\end{abstract}

Keywords :, Avicennia marina , tannin, immersion time

\section{Abstrak}

Buah mangrove mempunyai potensi untuk dikembangkan menjadi sumber pangan yang potensial, akan tetapi dalam buahnya mengandung tannin. Tanin merupakan zat alami yang dihasilkan oleh buah mangrove yang memberi rasa getir. Oleh karena itu, perlu dilakukan penelitian untuk mengurangi kadar tannin dalam buah mangrove. Tujuan penelitian ini adalah untuk menganalisis pengaruh perlakuan lama waktu perendaman air terhadap kadar tanin buah mangrove A.marina.Perlakuan lama perendaman air 24 jam 4 kali pergantian air (6 jam), 48 jam 8 kali pergantian air (6 jam), dan 72 jam 12 kali pergantian air (6 jam). Hasil penelitian menunjukan bahwa perlakuan lama perendaman air memberikan pengaruh yang nyata $(P<0.05)$ terhadap penurunan kadar tanin buah mangrove Avicennia marina. Perlakuan lama perendaman air 72 jam 12 kali pergantian air (6 jam) menurunkan kadar tanin sebesar $28,80 \%$.

Kata Kunci Avicennia marina, tanin, , lama perendaman air.

\section{PENDAHULUAN}

Masalah pangan di Indonesia tidak lepas dari sumber karbohidrat utama yaitu beras dan terigu, ternyata terigu lebih adaptif daripada pangan domestik seperti gaplek, beras jagung, sagu atau ubijalar. Meskipun di beberapa daerah penduduk masih mengkonsumsi makanan tradisional tersebut (Widowati et al., 2003). Upaya peningkatan dan pengembangan sumber bahan pangan potensial sudah banyak dilakukan. Hasil penelitian Wibowo et al., (2009) buah mangrove memiliki kandungan gizi yang lengkap, termasuk 
sumber karbohidrat dan kalori. Avicennia marina memiliki kandungan vitamin, lemak, kalori, asam amino, protein, serat, karbohidrat, dan mineral (Fe, Mg, Ca, K, $\mathrm{Na}$ ) dalam jumlah yang cukup tinggi pada daun dan buah.

Jenis buah mangrove yang sudah dimanfaatkan untuk bahan pangan yaitu buah mangrove jenis lindur (Bruquiera gymnorrhiza). Buah ini diolah secara tradisional menjadi kue, cake, dicampur dengan nasi atau dimakan langsung dengan bumbu kelapa, buah Sonneratia sp (buah pedada) dapat dibuat sirup, manisan dan Rhizophora sp buahnya dimanfaatkan untuk membuat anggur ringan. Avicennia sp. banyak tumbuh di daerah pesisir pantai utara Pulau Jawa, dan banyak dikenal dengan nama brayo atau api -api. A. marina sebagai bahan pangan bagi masyarakat pesisir, tetapi belum mengetahui bahwa buah Avicennia marina ini mengandung zat racun. Diduga racun dalam buah $A$. marina adalah tanin, menyebabkan rasa sepat dan bau langu, karena mengandung enzim lipoksigenase.

Menurut Sjostrom (1981) tanin adalah suatu senyawa polifenol dan dari struktur kimianya dapat digolongkan menjadi dua macam, yaitu tanin terhidrolisis (hidrolizable tannin) dan tanin terkondensasi (condensed tannin). Tanin terhidrolisis merupakan senyawa ester dari gula sederhana dengan satu atau lebih polifenol asam karboksilat, mudah mengalami hidrolisis dengan asam, basa, atau enzim. Senyawa ini dapat terpecah menjadi asam galat jika dilarutkan dalam air (Hagerman, 2002). Tanin terkondensasi (condensed tannins) menghasilkan asam klorida. Tanin jenis ini kebanyakan terdiri dari polimerflavonoid dan merupakan senyawa fenol (Hagerman, 2002). Tanin dihasilkan oleh tumbuhan hijau baik tumbuhan tingkat tinggi maupun tingkat rendah dengan kadar dan kualitas yang berbeda-beda. Menurut Markham (1988), sebagian besar flavonoid yang berasal dari hasil biosintesa (2\% dari seluruh karbon yang difotosintesis oleh tumbuhan) diubah menjadi tanin, sehingga flavonoid tersebut merupakan salah satu fenol alam yang terbesar.

Cara untuk mengurangi kadar tannin adalah perebusan dengan menambahkan bahan aktif yang baik terbuat dari material biologi (organik). Abu hasil pembakaran sekam padi merupakan sumber kalium dan mengandung silika/karbon. Menurut Chen dan Chang (1991) hasil pembakaran sekam padi menunjukkan kandungan $\mathrm{SiO}_{2}$ mencapai 80-90\% dan $15 \%$ berat abu akan diperoleh dari total berat sekam padi yang dibakar

Penelitian ini bertujuan untuk menganalisis kadar tannin dalam buah Avicennia marina dengan perlakuan perebusan dengan menggunakan abu gosok dan lama perendaman yang berbeda. Pengujian diharapkan dapat mengurangi kadar tannin dalam buah Avicennia marina sehingga aman untuk dikonsumsi.

\section{MATERI DAN METODE}

Bahan uji adalah buah Avicennia marina yang matang diambil langsung dari pohon. Perlakuan perebusan dengan kadar abu gosok $(5 \%, 10 \%$, dan $15 \%$ ) dan perlakuan lama perendaman air 24 jam 4 kali pergantian air (6 jam), 48 jam 12 kali pergantian air (6 jam), dan 72 jam 12 kali pergantian air (6 jam) (Ilminingtyas dan Kartikawati, 2009). Parameter yang diamati adalah kandungan tannin dalam buah A. marina. Sampel buah A.marina sebanyak $3,5 \mathrm{~kg}$, panjang $1,7-2,4 \mathrm{~cm}$, lebar 1,2-1,8 cm, dan berat 1,4-3,2 gram. Kriteria buah matang A.marina ditandai dengan warna hijau kekuningan, kulit buah sedikit mengelupas. Buah A. marina dikupas kulitnya dan bakal kecambah yang ada didalam diambil atau dibuang, didapatkan sekitar 3,2 kg buah digunakan untuk pelaksanaan penelitian. (Gambar 1 dan 2 buah A.marina).

Buah A. marina ditimbang sebanyak 5 g (3 ulangan) untuk dianalisis kadar tannin sebelum dilakukan perlakuan (kadar tannin awal dalam buah A. marina digunakan sebagai kontrol). Timbang 300 $\mathrm{g}$ buah tersebut masukkan kedalam panic 
(9 panci) berisi air (6 liter) dengan abu gosok (5\%, 10\%, dan 15\%) kemudian direbus. Perebusan dilakukan selama 20 menit menggunakan api kompor sedang dan diaduk terus menerus (llminingtyas dan Kartikawati, 2009). Setelah perebusan buah A.marina dicuci bersih dan ditiriskan. Buah ditimbang $5 \mathrm{~g}$ untuk dianalisis kadar taninnya dengan 3 kali pengulangan.

Buah A. marina kemudian ditimbang $250 \mathrm{~g}$ dan masukkan kedalam baskom $(9$ baskom) berisi 2 liter air. Buah direndam lama waktu yang berbeda 24 jam dengan pergantian air 4 kali setiap 6 jam ; 48 jam dengan pergantian air 8 kali setiap 6 jam dan 72 jam dengan pergantian air 12 kali setiap 6 jam. Buah A. marina diambil $5 \mathrm{~g}$ untuk dianalisis kadar taninnya. Tujuan dari pergantian air ini agar kualitas air tetap terjaga, sehingga buah $A$. marina yang direndam masih dalam kondisi baik. Buah A. marina diambil $5 \mathrm{~g}$ untuk dianalisis kadar taninnya dengan 3 kali ulangan.

\section{HASIL DAN PEMBAHASAN}

Buah A. marina yang sudah dikupas kulit dan dibuang bakal kecambahnya sebelum (kontrol) dan setelah perlakuan dianalisis kadar taninnya (Gambar 3)

Hasil analisis perebusan dengan kadar abu gosok yang berbeda memberikan pengaruh nyata $(P<0,05)$. Penurunan kadar tanin tertinggi pada perebusan kadar abu gosok $15 \%(0,0812$ $\%)$ dan terendah pada perebusan abu 5 $\%(0,1023 \%)$. Semakin tinggi kadar abu gosok kadar tanin dalam buah A. marina

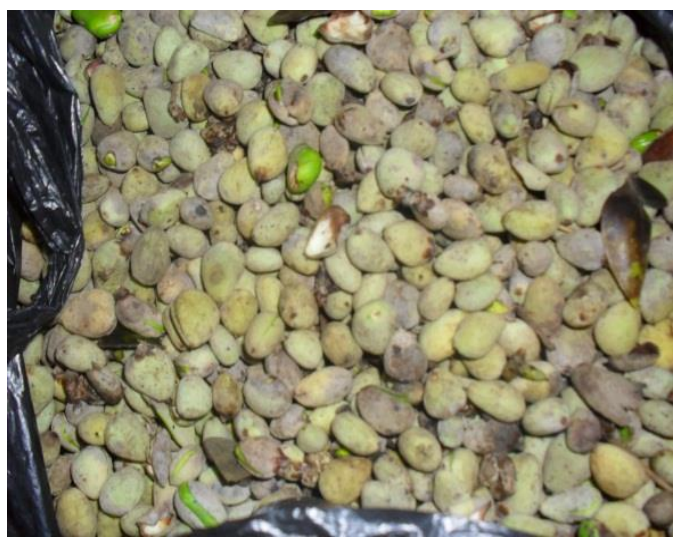

Gambar 1. Buah A. marina belum dikupas semakin menurun. Karena abu gosok dapat menghambat pembentukan oksidasi tannin dan mengikat tannin. Penggunaan abu gosok diduga dapat menginaktifkan enzim-enzim serta mengikat racun yang ada didalam buah mangrove A. marina secara adsorbsi. Tanin akan terurai menjadi glukosa dan asam galat, jika dipanaskan pada suhu 98-101 ${ }^{\circ} \mathrm{C}$. Abu gosok diketahui dapat menyerap cairan sel, mengikat racun dan mengikat zat antinutrisi. Nugroho (2009) tanin dapat dihidrolisa oleh asam, basa, dan enzim. Abu gosok termasuk dalam basa, karena mengandung $\mathrm{KOH}$.

Hubungan perlakuan perebusan dengan kadar abu gosok yang berbeda terhadap kadar tanin buah A.marina ini sangat erat dan mempunyai hubungan linier. Semakin tinggi kadar abu semakin rendah kadar tannin dalam buah $A$. marina $\left(r^{2}=0.953\right)$. (Gambar 4).

Hasil analisis kadar tanin buah A. marina perlakuan lama perendaman yang berbeda (Gambar 5).Penurunan kadar tanin terendah pada perebusan kadar abu gosok $15 \%$ dan perendaman air 72 jam 12 kali pergantian air (6 jam) $(0,0813 \%)$. Penurunan kadar tanin tertinggi pada perebusan abu dengan kadar $5 \%$ dan perendaman air 24 jam 4 kali pergantian air (6 jam) $(0,0955 \%$ ).

Hasil uji statistik lama perendaman yang berbeda berpengaruh nyata $(P<0,05)$ terhadap penurunan kadar tanin buah A. marina, karena lama perendaman dapat merubah struktur sel

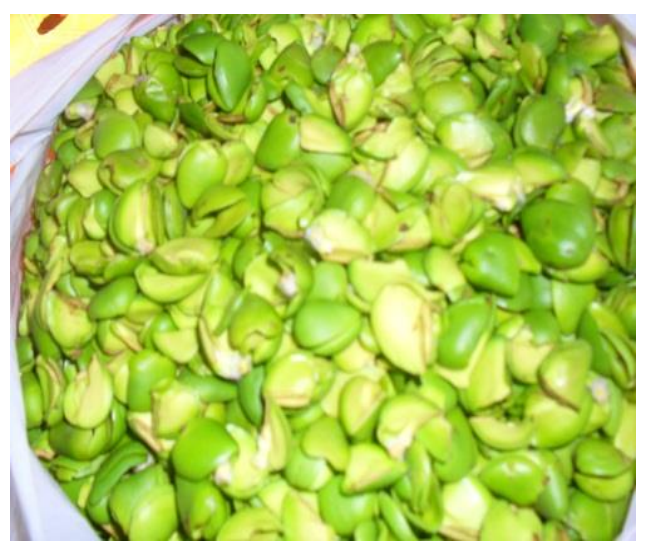

Gambar 2. Buah A. marina sudah dikupas 


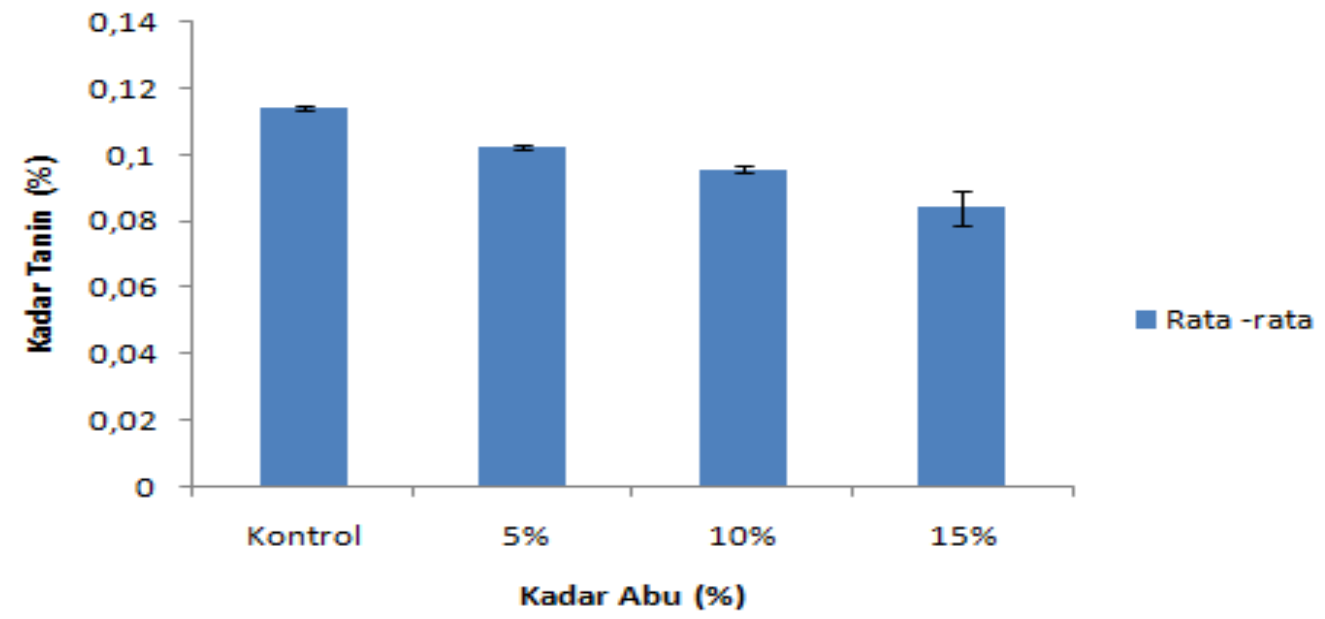

Gambar 3. Rata - Rata ( \pm SD) Kadar Tanin Buah A. marina Hasil Perebusan dengan Beberapa Kadar Abu Gosok

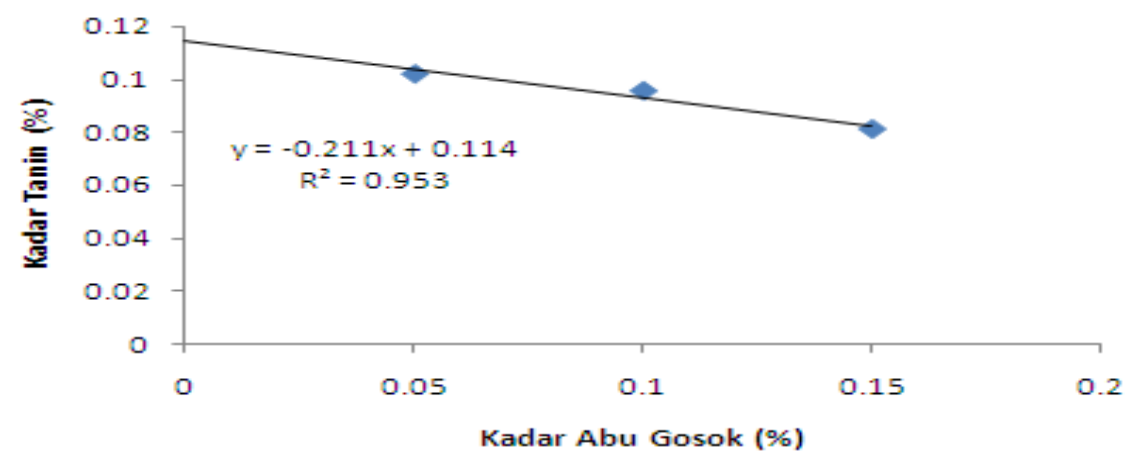

Gambar 4. Grafik Hubungan Perlakuan Kadar Abu Gosok terhadap Kadar Tanin Buah Mangrove A. marina selama perebusan

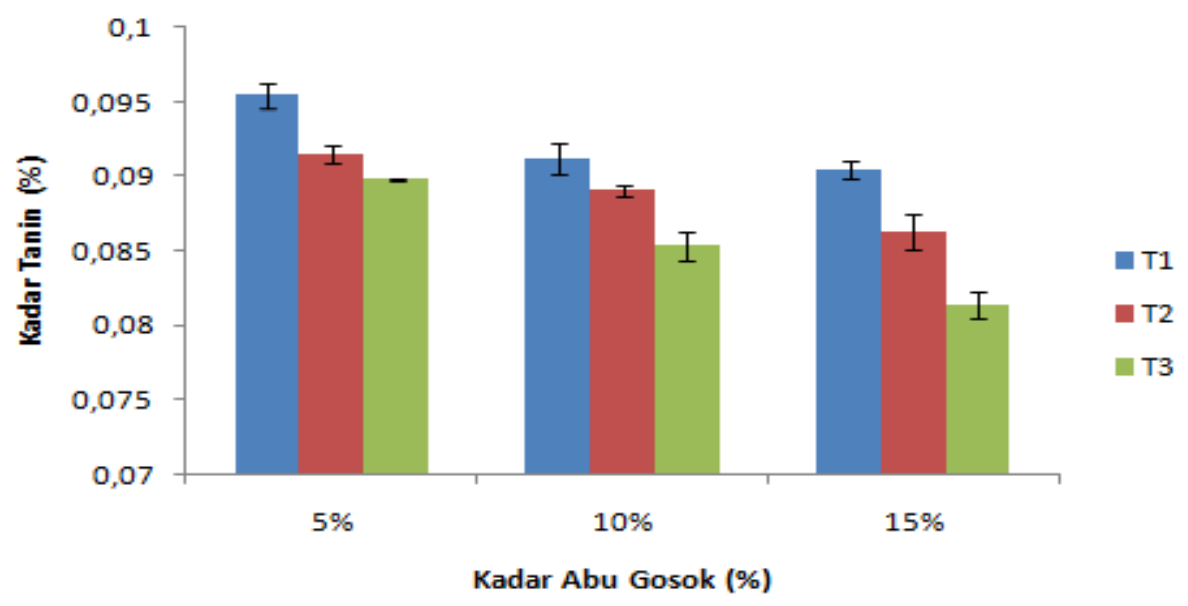

Gambar 5. Rata - Rata ( \pm SD) Kadar Tanin Buah A.marina Hasil Perendaman dengan Air

Keterangan : $\mathrm{Tl}=$ Perebusan dengan beberapa kadar abu gosok $(5 \%, 10 \%$, dan $15 \%)$ dan perendaman 24 jam dengan 4 kali pergantian air ( 6 jam), T2= Perebusan dengan beberapa kadar abu gosok $(5 \%$, $10 \%$, dan $15 \%$ ) dan perendaman 48 jam dengan 8 kali pergantian air $(6$ jam), T3= Perebusan dengan beberapa kadar abu gosok (5\%, $10 \%$, dan $15 \%$ ) dan perendaman 72 jam dengan 12 kali pergantian air (6 jam)

buah A. marina. Semakin lama buah direndam struktur buah menjadi lebih lunak, sehingga air lebih mudah masuk kedalam struktur selnya, peristiwa ini 
disebut imbibisi. Imbibisi merupakan proses penyerapan air oleh biji atau buah, buah A. marina akan menyerap air selama proses perendaman. Tanin bersifat larut dalam air dan dengan perendaman air dapat merombak atau menguraikan tanin, sehingga tanin banyak yang larut dan terbawa oleh air. Proses perendaman diduga dapat mengeluarkan tanin yang terikat dengan abu gosok dan proses ini terjadi saat pergantian air. Selama perendaman dilakukan penggantian air setiap 6 jam sekali, bertujuan kualitas air tetap terjaga. Perendaman berpengaruh terhadap kesegaran buah A. marina, serta mencegah timbulnya mikroorganisme yang menyebabkan pembusukan.

Hubungan antara perlakuan perebusan dengan kadar abu gosok yang berbeda ( $y=-0,062 X+0,095$ Gambar 6) dan perlakuan lama perendaman air ( $y=$ $-0,000 X+0,095$ Gambar 7)terhadap kadar tanin buah mangrove A.marina berpola linier. Nilai korelasi menunjukkan hubungan yang erat semakin tinggi kadar abu gosok dan lama perendaman air semakin rendah kadar tanin buah mangrove $A$. marina.

Penelitian ini membuktikan perlakuan perebusan dan lama waktu perendaman memiliki manfaat dalam menurunkan kadar tanin dalam buah $A$. marina. Karena saat perebusan dan perendaman terjadi proses difusi dan osmosis. Proses difusi ini terjadi pada saat perebusan dengan kadar abu. Semakin tinggi kadar abu semakin rendah kadar tanin dalam buah A. marina, karena pengaruh dari abu tersebut. Menurut Danarto (2008) difusi dapat terjadi jika kadar larutan yang ada didalam sel tinggi maka larutan akan keluar sel yang kadar larutannya rendah. Proses ini terjadi agar kadar larutan seimbang

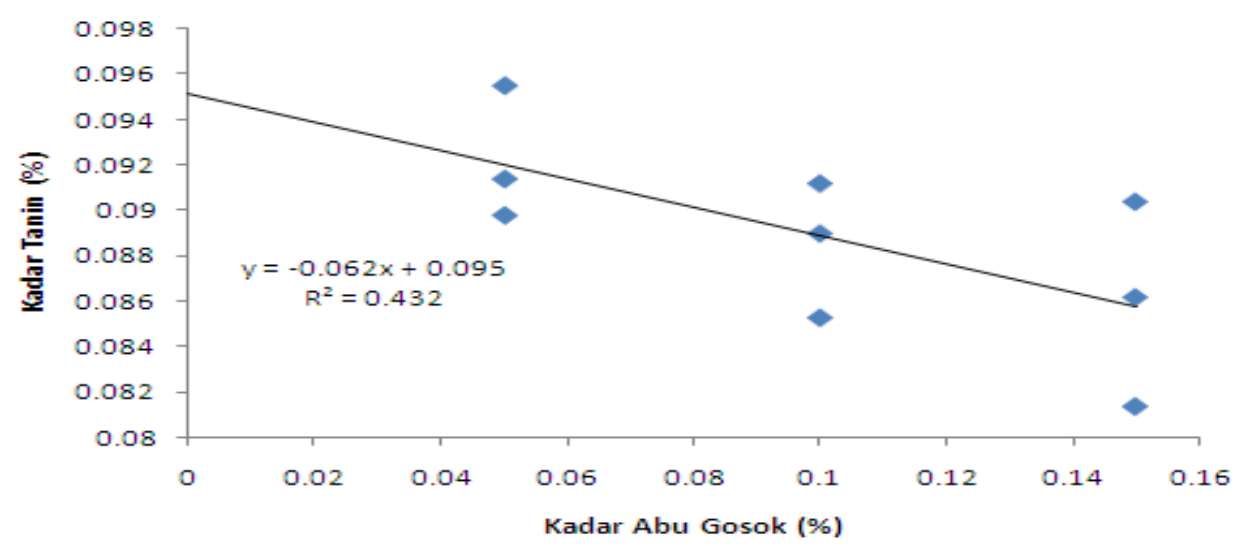

Gambar 6. Grafik Hubungan Perlakuan Kadar Abu Gosok terhadap Kadar Tanin Buah A. marina setelah perebusan

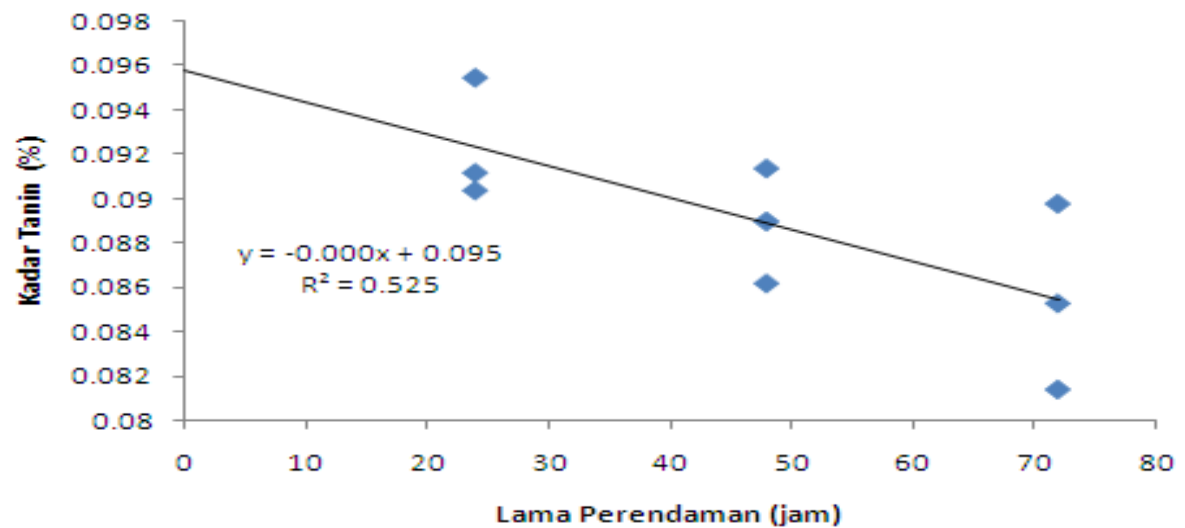

Gambar 7. Grafik Hubungan Perlakuan Lama Perendaman Air terhadap Kadar Tanin Buah Mangrove A. marina. 
Difusi pada saat perendaman terjadi dengan larutnya sisa zat yang ada pada buah. Hal ini ditandai dengan kondisi air yang berubah warna atau berbuih. Diduga salah satu zat yang larut ini adalah tanin karena sifat tanin sendiri yang mudah larut dalam air. Sebaliknya osmosis adalah proses perpindahan atau pergerakan zat dari larutan yang konsentrasi rendah menuju larutan yang konsentrasi tinggi, melalui membrane selektif permeabel atau semi permeable. Proses osmosis terjadi saat proses perebusan dimana zat yang ada pada buah akan keluar terbawa air. Sedangkan pada proses perendaman air konsentrasi larutan rendah akan berpindah ke dalam buah yang konsentrasi larutan tinggi, sehingga kandungan air buah tinggi dan sedikit mengembang.

Hasil analisis kandungan tannin berkurang pada perlakuan perebusan dengan kadar abu $15 \%$. Sedangkan perlakuan lama perendaman air 72 jam 12 kali pergantian air setiap 6 jam memberikan hasil yang berbeda nyata dibandingkan dengan perlakuan perendaman yang lain

\section{KESIMPULAN}

Perlakuan perebusan dengan abu gosok dan lama perendaman air, memberikan pengaruh nyata terhadap penurunan kadar tannin buah Avicennia marina $(P<0,05)$. Perlakuan pemberian kadar abu gosok $15 \%$ dan lama perendaman perendaman air 72 jam 12 kali pergantian air (6 jam) menurunkan kadar tannin yang efektif

\section{DAFTAR PUSTAKA}

Danarto, Y.C. 2008. Pirolisis Sekam Padi dengan Katalisator Zeolit. Prosiding Seminar Nasional Kimia dan Pendidikan Kimia, FMIPA dan UNS.

Chen, J-M \& Chang, F-W, 1991. The Chlorination Kinetics of Rice Hull, Ind. Eng. Chem. Res., 30, pp. 2241-2247.

Hagerman, A.E. 2002. Condensed Tannin Structural Chemistry. Department of Chemistry and Biochemistry, Miami, University Oxford OH 45046
Ilminingtyas, D.W.H \& Kartikawati, D. 2009. Potensi Buah Mangrove Sebagai Alternatif Sumber Pangan. Universitas 17 Agustus, Semarang. 15-22 pp.

Markham, K. R. 1988. Cara Mengidentifikasi Flavonoid. Terjemahan. Istitut Teknologi Bandung. Bandung.

Nugroho, F. 2009. Manfaat abu sekam. http://febrynugroho.wordpress.com/ (diakses Juli 2017).

Sjostrom, e. 1981. Kimia Kayu Dasar - Dasar dan Penggunaan. Edisi 2 (Terjemahan). Yogyakarta: Gadjah Mada University Press.

Wibowo, Kusmana, C.C., Suryani, A., Hartati, Y. \& Oktadiyani, P. 2009. Pemanfaatan Pohon Mangrove Apiapi (Avicennia sp.) sebagai Bahan Pangan dan Obat. IPB, Bogor. 160-165 $\mathrm{pp}$

Widowati, S., L. Sukarno, Suarni dan $O$. Komalasari, 2003. Labu Kuning : Kegunaan dan Proses Pembuatan Tepung. Makalah pada seminar Nasional dan Pertemuan Tahunan Perhimpunan Ahli Teknologi Pangan Indonesia (PATPI) 22-23 Juli 2003 di Yogyakarta. HIm 30-38 